\title{
Joggyakorlat
}

\section{Az őslakos népek kulturális identitáshoz való joga az Emberi Jogok Amerikaközi Bírósága joggyakorlatában}

\author{
The Indigenous Peoples' Right to Cultural Identity \\ the Case-law of the Inter-American Court of Human Rights
}

\begin{abstract}
ABSZTRAKT
Jelen tanulmány a kulturális identitás védelmét vizsgálja az Emberi Jogok Amerikaközi Bíróságának (EJAB) gyakorlatában, ahol a kérdéskör elsősorban az őslakos népek kontextusában jelenik meg. Az EJAB a kulturális identitáshoz való jog védelmét - az ezt garantáló, anyagi jogi norma hiányában - jellemzően az élethez és a tulajdonhoz való jogból, valamint egyéb, első generációs emberi jogokból vezeti le evolutív módon, az Emberi Jogok Amerikai Egyezményére (EJAE) támaszkodva. 2020 tavaszán a Lhaka Honhat kontra Argentína ügyben hozott itéletében az EJAB új perspektívát nyitott a kulturális identitáshoz való jog védelmére, mert megállapította, hogy a kulturális jogok önállóan, autonóm módon is érvényesithetők az EJAB elött, az EJAE 26. cikke alapján. Ez, az EJAB eddigi joggyakorlatához képest haladó szemlélet egyúttal új lehetőségeket nyit meg az EJAE 26. cikkéböl eredeztethetö környezetvédelmi jogok érvényesithetösége terén is.
\end{abstract}

Kulcsszavak: kulturális identitáshoz való jog, kulturális jogok, őslakos népek, Emberi Jogok Amerikaközi Bírósága, második generációs emberi jogok

\begin{abstract}
The present paper examines the protection of cultural identity in the case-law of the InterAmerican Court of Human Rights (IACHR), where this question has primarily been dealt with in connection with the rights of indigenous peoples. Although not expressly guaranteed in the American Convention on Human Rights (ACHR), the right to cultural identity is found to be protected in the treaty due to the IACHR's evolutionary interpretation of the right to life and the right to property, as well as other first-generation human rights contained in the ACHR. Issued in the Spring of 2020, the IACHR decision in the case Lhaka Honhat vs Argentina puts into a new perspective the protection of the right to cultural identity. Unlike before, it was clearly established
\end{abstract}

* Dr. Zombory Katarzyna, kutató, Mádl Ferenc Összehasonlító Jogi Intézet, Budapest; e-mail: katarzyna. zombory@mfi.gov.hu. 
that cultural rights are autonomous and judicially enforceable under Article 26 of the ACHR. At the same time, the ICHR's revolutionary approach provides new opportunities for the judicial protection of environmental rights claims based on Article 26 of the ACHR as well.

Keywords: right to cultural identity, cultural rights, indigenous peoples, Inter-American Court of Human Rights, second-generation of human rights

Napjainkban világszerte a termöföld és a természeti erőforrások iránti növekvő kereslet figyelhető meg, amely az őslakos népek által birtokolt és természeti kincsekben gazdag területeket is érinti. A különböző gazdasági ágazatokban megvalósuló nagyberuházási projektek elöre vetítik a földtulajdonnal kapcsolatos konfliktusokat, több esetben pedig visszafordíthatatlan környezetkárosodáshoz és a helyi őslakosok erőszakos kitelepítéséhez, ezáltal pedig a kulturális identitásuk elvesztéséhez is vezetnek. ${ }^{1}$ Ilyen körülmények között a gyakran eleve hátrányos helyzetben élő őslakos népeket - sokadjára a történelmük során - a földjeik elvesztése és a kulturális genocídium fenyegeti. Ugyanakkor, a kulturális identitáshoz való joguk védelmét az őslakosok éppen a modern civilizáció vívmánya, az emberi jogvédelmi rendszer segítségével keresik a nemzetközi fórumokon. A jelen tanulmány az Emberi Jogok Amerikaközi Bíróságának (a továbbiakban: EJAB vagy Bíróság) a kulturális identitás védelméhez kapcsolódó ítélkezési gyakorlatát vizsgálja, amely 2020 tavaszán újabb, jelentős fordulatot vett. Érdemes megismerni ennek, az őslakosok jogai védelme terén legnagyobb tekintéllyel rendelkező nemzetközi bíróságnak a megközelítését, amely a kulturális identitáshoz való jog védelmét rendkívül széles alapokra helyezi, immár a vízhez, a megfelelő élelemhez és az egészséges környezethez való jogra is támaszkodva.

Ami az EJAB szervezeti elhelyezkedését illeti, az 1979 óta működő, San José-i székhelyű bíróság az Amerikai Államok Szervezete (AÁSZ) égisze alatt zajló emberi jogvédelem egyik legföbb pillére. ${ }^{2}$ Működési alapját az Emberi Jogok Amerikai Egyezménye (továbbiakban: EJAE) ${ }^{3}$ képezi. Az Amerika-közi mechanizmusban két, az emberi jogi kötelezettségek betartását ellenőrizni hivatott intézmény müködik. A Bíróságon kívül ezt a feladatot az Emberi Jogok Amerikaközi Bizottsága (továbbiakban: EJABiz) is ellátja. ${ }^{4} \mathrm{Az}$ EJABiz szürő funkciójából adódóan - ugyanis csak

\footnotetext{
Az őslakos népeket érintő jogsértésekről lásd bővebben: az Európai Parlament Külügyi Bizottsága által készített jelentés a világban az őslakos népeket érő jogsértésekről, beleértve a nagyarányú földszerzést, 2018. május 29., A8-0194/2018; az ENSZ őslakos népekkel foglalkozó különleges jelentéstevője által készített jelentések, például a nemzetközi beruházásoknak az őslakosok jogaira gyakorolt hatásait vizsgáló 2016 . augusztus 11-i jelentés [Report of the Special Rapporteur on the rights of indigenous peoples] A/HRC/33/42, illetve a 2016. július 29-i jelentés [Rights of indigenous peoples], A/71/229.

2 Bővebben lásd RAIsz Anikó: Az emberi jogok fejlődése az Emberi Jogok Európai és Amerikaközi Bíróságának kölcsönhatásában. Novotni Kiadó, Miskolc, 2010, 15-23.; MARINKÁs György: Az őslakos népek védelmének aktuális jogi kihívásai. Miskolci Egyetem Állam- és Jogtudományi Kar, Miskolc, 2018, 108-111. (DOI: 10.14750/ME.2016.011)

${ }^{3}$ Az Emberi Jogok Amerikai Egyezménye [American Convention on Human Rights], San José, 1969. november 22.

${ }^{4}$ Azzal a különbséggel, hogy az EJABiz nem kötelező, az EJAB pedig kötelező erejű döntéseket hoz. $\mathrm{Az}$ EJAB csak olyan államok esetén rendelkezik joghatósággal, amelyek ratifikálták az EJAE-t, ezzel szem-
} 
rajta keresztül kerülhet egy ügy az EJAB elé, ha a súlyossága ezt indokolja - a bírósági fázisba eljutó ügyek szisztematikus és/vagy súlyos jogsértésekről szólnak. Így az EJAB által elbírált, az őslakos népeket érintő ügyek sokszor olyan súlyos problémákat is érintenek, mint kényszer-kitelepítések, erőszakos eltünések, gyilkosságok vagy tömegmészárlások.

\section{A kulturális identitáshoz való jog az Amerika-közi emberi jogi dokumentumokban}

A kulturális identitás a kollektív identitás egyik fajtája. A szakirodalomban a kulturális identitást úgy definiálják, mint azoknak a tényezőknek az összessége, amelyek alapján egy személy vagy csoport kifejezésre jut, „önrendelkezik” és felismerhetővé válik. ${ }^{5} \mathrm{~A}$ kulturális identitáshoz való jog a mássághoz való jog elismerését feltételezi, magában foglalja az egyéneknek és a csoportoknak egy adott kultúrához való tartozása jogát, valamint a tárgyi és szellemi kulturális örökség megőrzéséhez és az erőszakos asszimiláció elleni védelemhez való jogot is. ${ }^{6}$ Egyes nézetek szerint a kulturális identitáshoz való jog valamennyi kulturális jog általános megtestesülése. ${ }^{7}$

Az Amerika-közi emberi jogvédelmi rendszerben a kulturális identitás védelmét elsősorban az őslakos népek és kultúrák kontextusában vizsgáljuk. Az őslakos kultúrák különleges helyzetű kisebbségi kultúrák, amelyeket egy-egy terület (földrész) meghódítása előtt a domináns helyzetben lévő népek hoztak létre. ${ }^{8}$ Mivel különleges kapcsolatuk van a földdel és a környezettel, amely az identitásuk és spiritualitásuk alapvető részét képezi, ezért különleges igényeik merülnek fel, mint a földtulajdoni és földhasználati jogok, ideértve a területhez kapcsolódó természeti erőforrások feletti rendelkezés jogát, továbbá ezekből eredő kompenzációs jogok illetik meg őket. Az ENSZ Emberi Jogi Bizottsága (továbbiakban: ENSZ EJB) véleményében ez a sa-

ben az EJABiz azon államok tekintetében is eljárhat, amelyek nem ismerték el az EJAB joghatóságát. A panaszjogból indult eljárásokon kívül az EJAB jelentős szerepet tölt be az Amerika-közi jogvédelmi rendszerben a tanácsadó véleményezési gyakorlata miatt is, amelynek vizsgálata azonban meghaladja jelen tanulmány kereteit.

${ }^{5}$ KARTAG-Ódri Ágnes-Sımović-HıBER, Ivana: A kultúra és identitás (emberi) jogi aspektusai. Létünk, 1997/34, 294. Lásd a Fribourgi Csoport által kidolgozott, a kulturális jogokról szóló Fribourgi Nyilatkozat [Fribourg Declaration on Cultural Rights], Fribourg, 2007. május 7., 2. cikk (b) pont; valamint BíRó Gáspár: Az identitásválasztás szabadsága. Osiris-Századvég, Budapest, 1995, 213.

${ }^{6}$ Ruiz-Chiriboga, Oswaldo: The Right to Cultural Identity of Indigenous Peoples and National Minorities: A Look from the Inter-American System. SUR-International Journal on Human Rights, 2006/5, 45.

7 DONDERS, Yvonne: A Right to Cultural Identity in UNESCO. In: Francioni, Francesco-Scheinin, Martin (eds.): Cultural Human Rights. Martinus Nijhoff Publishers, Boston-Leiden, 2008, 320. Janusz Symonides a kulturális identitáshoz való jog helyett a kulturális identitás tiszteletben tartásának joga kifejezés használatát javasolta, amely szerint mindenkinek - egyénileg vagy másokkal alkotott közösségben - jogában áll szabadon megválasztani a saját kulturális identitását annak különböző aspektusaiban, mint a nyelv, vallás, örökség és hagyományok, valamint mindenki szabadon dönthet arról, hogy egy vagy több kulturális közösséghez tartozóként azonosítja magát. Lásd SymonidES, Janusz: Cultural Rights. In: Symonides, Janusz (ed.): Human Rights: Concepts and Standards. Dartmouth Publishing, Dartmouth, 2000, 189.

${ }^{8}$ KARDOs Gábor: Kultúrához való jog védelme a nemzetközi jogban. Fundamentum, 2002/2, 35. Az őslakos népek definíciójával kapcsolatban bővebben lásd MARINKÁs (2018): i. m., 12-38. 
játos életforma, amely a földhöz és a természeti kincsek felhasználásához szorosan kötődik, az őslakos népek kultúrájának a megnyilvánulása, ezért védelmet érdemel a kulturális jogok alapján. ${ }^{9}$ Kardos Gábor szerint az őslakos népek jogai lényegében kulturális jogok. ${ }^{10} \mathrm{~A}$ természeti erőforrások állandóságától és elérhetőségétöl közvetlenül függő életmódjuk, és a földhöz füződő szoros kapcsolatuk miatt az őslakos népek a környezetkárosítás és a klímaváltozás negatív hatásai által leginkább érintett csoportok közé tartoznak.

Az Amerika-közi emberi jogvédelmi rendszer keretében a gazdasági, szociális és kulturális jogok szempontjából három releváns nemzetközi dokumentum került elfogadásra: (1) az 1948-as Emberi Jogok és Kötelezettségek Amerikai Nyilatkozata ${ }^{11}$ (a továbbiakban: EJKA Nyilatkozat), (2) az 1969-ben aláírt, fentebb említett Emberi Jogok Amerikai Egyezménye (EJAE), valamint (3) az 1988-ban elfogadott a gazdasági, szociális és kulturális jogokról szóló San Salvadori Kiegészítő Jegyzőkönyv (a továbbiakban: San Salvadori Jegyzökönyv). ${ }^{12} \mathrm{Az}$ említett három nemzetközi dokumentum közül egyik sem utal expressis verbis a kulturális identitáshoz való jogra. Az EJKA Nyilatkozat a kulturális életben való részvétel jogát rögzíti, mint minden embert megillető jogot, ám a jelentősége korlátozott amiatt, hogy nem kötelező erejủ nemzetközi dokumentum. Az EJAE azon túl, hogy a 26. cikke elöírja a szerződő államoknak az AÁSZ Chartában ${ }^{13}$ szereplő gazdasági, szociális és kulturális jogok fokozatos megvalósítása iránti elköteleződését, nem tartalmaz kulturális jogokra vonatkozó előírásokat. Az EJAE 26. cikkének gyakorlati jelentősége sokáig vitatott volt programszerü jellege miatt, ${ }^{14}$ mégis a legújabb ítélkezési gyakorlat fényében megállapítható, hogy ilyen programjellegü garanciák is alkalmasak lehetnek az őslakos népek kulturális identitásának védelmére. A San Salvadori Jegyzőkönyv ugyan tartalmazza a kulturális életben való részvétel jogát, amely jog azonban, a Jegyzökönyvben garantált többi joghoz hasonlóan (az oktatáshoz való jog és a szakszervezeti jogok kivételével) nem érvényesíthető bírósági úton. ${ }^{15}$

${ }^{9}$ Az ENSZ Emberi Jogi Bizottságának a kisebbségek jogairól szóló 23. számú általános kommentárja [UN Human Rights Committee, CCPR General Comment No. 23: Article 27 (Rights of Minorities)], 1994. április 8., CCPR/C/21/Rev.1/Add.5, 3.2. és 7. pont. Ezen a szemléleten alapul az Öslakos Népek Jogairól Szóló ENSZ Deklaráció is [UN Declaration on the Rights of Indigenous Peoples], az ENSZ Közgyülés 2007. szeptember 13-i határozata, A/RES/61/295.

10 KARDOS: i. m., 35.; MARINKÁS György: Kulturális jogok az őslakos népek védelmének szolgálatában. Publicationes Universitatis Miskolcinensis, Sectio Juridica et Politica, Tomus XXXII (2014), 164.

${ }^{11}$ Az Emberi Jogok és Kötelezettségek Amerikai Nyilatkozata [The American Declaration of the Rights and Duties of Man], Bogotá, 1948. május 2.

${ }^{12}$ A gazdasági, szociális és kulturális jogokról szóló San Salvadori Kiegészítő Jegyzőkönyv [Additional Protocol to the American Convention on Human Rights in the Area of Economic, Social and Cultural Rights, „Protocol of San Salvador"], San Salvador, 1988. november 17., OAS Doc. OAS/Ser.L/V/I.4 rev. 13.

${ }^{13}$ Az Amerikai Államok Szervezetének Chartája [Charter of the Organization of American States], Bogotá, 1948. április 30.

${ }^{14}$ RuIz-CHIRIBogA, Oswaldo: The American Convention and the Protocol of San Salvador: Two Intertwined Treaties. Netherlands Quarterly of Human Rights, 2013/2, 160-162.; RAISz Anikó: Az emberi jogok amerikaközi védelme. Publicationes Universitatis Miskolcinensis, Sectio Juridica et Politica, Tomus XXVIII. (2010), 290.

${ }^{15}$ San Salvadori Jegyzőkönyv 19. cikk (6). 


\section{Az EJAB joggyakorlatának áttekintése}

A kulturális identitáshoz való jog, annak ellenére, hogy azt az EJAE nem garantálja expressis verbis, védelemben részesül az EJAE rendelkezései alapján, annak evolutív (jogfejlesztő) értelmezése révén. ${ }^{16} \mathrm{Az}$ Emberi Jogi Amerikaközi Bíróság ítéleteiben a kulturális identitáshoz való jog védelme több alapjoghoz kapcsolódóan, a meglévő anyagi jogi rendelkezésekből eredeztetve jelenik meg. Ahogy arra az EJAB egyik bírája rámutatott, a kulturális identitás védelmére alkalmas jogi garanciák spektruma igen széles. ${ }^{17}$ Jellemzően az őslakos népeket érintő ügyekben az EJAB olyan módon értelmezi az EJAE-ban garantált jogokat, hogy elismeri az őslakos közösségeket megillető jogok kollektív jellegét, vagy legalább azok kollektív dimenzióját, illetve az őslakos közösségek kollektív jogalanyiságát. ${ }^{18}$

Időben leghamarabb az EJAB az élethez való jog (EJAE 4. cikke) kiterjesztő értelmezése révén részesítette védelemben a nem többségi kultúrák identitását, illetve annak különböző elemeit, elsősorban az élök és a holtak közötti kötelékre épülő hitvilágot. Így született a vida digna koncepció, amely szerint az élethez való jog a méltó élethez való jogra is kiterjed. ${ }^{19} \mathrm{~A}$ Bíróság értelmezésében a méltó élet védelme feltételezi a kulturális szokások és a vallási meggyőződések tiszteletben tartását is. ${ }^{20}$

${ }^{16}$ CANÇAdo Trindade, Antônio Augusto: The Right to Cultural Identity in the Evolving Jurisprudential Construction of the Inter-American Court of Human Rights. In: Yee, Sienho-Morin, Jacques-Yvan (eds.): Multiculturalism and International Law. Martinus Nijhoff Publishers, Boston-Leiden 2009, 477-499.; RuIzCHIRIBOGA (2006): i .m., 51.; MARINKÁs (2018): i. m., 110. Az evolutív értelmezési módszer (azaz az „élő jog” megközelítés) az Emberi Jogok Európai Bírósága joggyakorlatában jelent meg először, ezzel kapcsolatban lásd bővebben LETSAS, George: The Truth in Autonomous Concepts: How To Interpret the ECHR. European Journal of International Law, 2004/2, 20.

${ }^{17}$ Alirio Abreu Burelli bíró különvéleménye a Yakye Axa kontra Paraguay ügyben, 24. pont. A bíró szerint a kulturális identitáshoz való jog, bár nem garantált expressis verbis az EJAE-ben, a konkrét ügy körülményeitől függően védelemben részesülhet, például az EJAE 1.1. (a diszkrimináció tilalma), 5. (az emberséges bánásmódhoz való jog), 11. (a magánélethez való jog), 12. (a lelkiismereti és vallásszabadsághoz való jog), 13. (vélemény- és szólásszabadsághoz való jog), 15. (a gyülekezési jog), 16. (az egyesülési szabadsághoz való jog), 17. (a család jogai), 18. (a névhez való jog), 21. (a tulajdonhoz való jog), 23. (a közügyekben való részvétel joga), 24. (az egyenlőséghez való jog) cikke alapján, e jogok evolutív értelmezése révén.

${ }^{18}$ HohmanN, Jessie: The UNDRIP and the Rights of Indigenous Peoples to Existence, Cultural Integrity and Identity, and Non-Assimilation. Articles 7(2), 8 and 43. In: Hohmann, Jessie-Weller, Marc (eds.): The UN Declaration on the Rights of Indigenous Peoples. A Commentary. Oxford University Press, Oxford, 2018, 162. (DOI: 10.1093/law/9780199673223.003.0007); MARINKÁs (2018): i. m., 238.

19 CançAdo Trindade: i. m., 479-481. Lásd bővebben PAsqualucci, Jo M.: The Right to a Dignified Life (Vida Digna): The Integration of Economic and Social Rights with Civil and Political Rights in the Inter-American Human Rights System. Hastings International and Comparative Law Review, 2008/1, 1-32. Az élethez való jog kiterjesztő értelmezése és a vida digna védelme az EJAB sajátossága, ezzel szemben például az Ember és Népek Jogainak Afrikai Bírósága (ENJAB) arra az álláspontra helyezkedett, hogy az élethez való jog, amelyet az Ember és a Népek Jogainak Afrikai Chartája a 4. cikkében garantál, az egyén fizikai létét helyezi védelem alá, és nincs egzisztenciális vetülete (lásd az ENJAB-nak az Emberek és Népek Jogainak Afrikai Bizottsága kontra Kenya ügyben 2017. május 26-án született ítéletét, 153-154. pont).

${ }^{20} \mathrm{Ez}$ az értelmezés jutott érvényre olyan ügyek elbírálásánál, mint a Villagrán-Morales és társai kontra Guatemala ügy, 1999. november 19-i ítélet [Case of the "Street Children" (Villagrán Morales et al.) v. Guatemala. Merits. Judgment of November 19, 1999. Series C No. 63]; a Bámaca Velásquez kontra Guatemala ügy, 2000. november 25-i ítélet [Case of Bámaca Velásquez v. Guatemala. Merits. Judgment of November 25, 2000. Series C No. 70.]; a Yakye Axa őslakos közösség kontra Paraguay ügy, 2006. február 6-i ítélet [Case 
Cançado Trindade és Ventura Robles bírák rámutattak, hogy a kulturális identitás a tágabb értelemben vett élethez való jognak integráns részét képezi, vagy szorosan összefügg vele. Emiatt, ha az öslakos közösség kulturális identitása sérül, ezzel egyidejüleg az egész közösség élethez való joga is sérül. ${ }^{21} A z$ EJAB joggyakorlatában az őslakosok kulturális identitásának védelme összefonódik a fizikai túléléssel és az élet védelmével, amely határozottan szemben áll az amerikai kontinensek történetében ismert és bizonyos helyeken most is zajló erőszakos asszimilációval, és rávilágít a kulturális népirtás és etnocídium problémájára. ${ }^{22}$

A Mayagna (Sumo) Awas Tingni kontra Nicaragua ügy (2001) óta, amelyben az EJAB az őslakos népek védelmét a kollektív tulajdonhoz való jogra alapozta, az Amerika-közi mechanizmusban a kulturális identitáshoz való jog védelme legföképp a (föld-) tulajdonhoz való jog keretében valósul meg (EJAE 21. cikke). ${ }^{23}$ A Bíróság ítélkezési gyakorlatában arra az álláspontra helyezkedett, hogy az ősi földtulajdonosi és földhasználati jogok megtagadása olyan alapvető jogok megsértéséhez vezethet, mint a kulturális identitáshoz, vagy a túléléshez való jog. ${ }^{24} \mathrm{Az}$ EJAB számos alkalommal kifejtette az összefüggést az öslakos közösségek emberemlékezet óta birtokolt földje, és kulturális identitásuk között. A Bíróság megítélésében az őslakos népek és a földjeik közötti szoros összefüggés a kulturális identitásuk lényeges ele-

of the Yakye Axa Indigenous Community v. Paraguay. Interpretation of the Judgment of Merits, Reparations and Costs. Judgment of February 6, 2006. Series C No. 142]; a Sawhoyamaxa öslakos közösség kontra Paraguay ügy, 2006. március 29-i ítélet [Case of the Sawhoyamaxa Indigenous Community v. Paraguay. Merits, Reparations and Costs. Judgment of March 29, 2006. Series C No. 146].

${ }^{21}$ Antônio Cançado Trindade és Manuel Ventura Robles bírák különvéleménye a Yakye Axa kontra Paraguay ügyben, 18.-19. pont.

22 Hohmann: i. m., 151. Xanthaki, Alexandra: Culture. Articles 11(1), 12, 13(1), and 34. In: Hohmann, JessieWeller, Marc (eds.): The UN Declaration on the Rights of Indigenous Peoples. A Commentary, Oxford University Press, Oxford, 2018, 274. (DOI: 10.1093/law/9780199673223.003.0011)

${ }^{23}$ A Mayagna ügyet követően az EJAB számos ítéletben részesítette védelemben az öslakosoknak a földdel és a természetes erőforrásokkal való kötelékét az EJAE 21. cikke alapján. A teljesség igénye nélkül: Yakye Axa öslakos közösség kontra Paraguay ügy (2006); Sawhoyamaxa őslakos közösség kontra Paraguay ügy (2006); Saramaka nép kontra Suriname ügy, 2007. november 28-i itélet [Case of the Saramaka People v. Suriname. Preliminary Objections, Merits, Reparations, and Costs. Judgment of November 28, 2007 Series C No. 172]; Sarayakui Kichwa öslakos nép kontra Ecuador ügy, 2012. június 27-i ítélet [Case of Kichwa Indigenous People of Sarayaku v. Ecuador. Merits and Reparations. Judgment of June 27, 2012. Series C No. 245]; Madungandiii Kuna és Bayanoi Emberá nép és tagjaik kontra Panama ügy, 2014. október 14-i ítélet [Case of the Kuna Indigenous People of Madungandí and the Emberá Indigenous People of Bayano and their Members v. Panama]; Kaliña és Lokono népek kontra Suriname ügy, 2015. november 25-i ítélet [Case of the Kaliña and Lokono Peoples v. Suriname. Merits, Reparations and Costs. Judgment of November 25, 2015. Series C No. 309]; Xucuru őslakos nép és a tagjai kontra Brazília ügy, 2017. február 5-i ítélet [Case of the Xucuru Indigenous People and its members v. Brazil. Preliminary Objections, Merits, Reparations and Costs. Judgment of February 5, 2017. Series C No. 346]; Lhaka Honhat kontra Argentína ügy, 2020. február 6-i itélet [Case of the Indigenous Communities of the Lhaka Honhat Association (Our Land) v. Argentina. Merits, Reparations and Costs. Judgment of February 6, 2020. Series C No. 400]. Lásd bővebben MARINKÁs György: Az őslakos népek földhöz való joga és egyes környezetjogi kérdések. Publicationes Universitatis Miskolcinensis, Sectio Juridica et Politica, Tomus XXXIII (2015), 275.; RAISz Anikó: Földtulajdoni és földhasználati kérdések az emberi jogi bíróságok gyakorlatában. In: Csák Csilla (szerk.): Az európai földszabályozás aktuális kihívásai. Novotni Kiadó, Miskolc, 2010, 250-252.

${ }^{24}$ Yakye Axa kontra Paraguay ügyben hozott ítélet (2006), 147. pont; Sarayakui Kichwa öslakos nép kontra Ecuador ügyben hozott ítélet (2012), 212. pont. 
me, amelyet egy demokratikus társadalomban kifejezetten el kell ismerni; és tiszteletben kell tartani. ${ }^{25} \mathrm{Az}$ őslakos népeknek a földdel való köteléke a kultúrájuknak, spirituális életüknek, integritásuknak és gazdasági túlélésüknek az alapja. ${ }^{26}$ Közölte továbbá, hogy az őslakos népek esetén a föld nem pusztán a birtokviszonyok tárgya és egy termelési eszköz, hanem spirituális tényező is, amelynek szem előtt tartása elengedhetetlen a kulturális örökség megóvásához és továbbadásához. ${ }^{27}$

$E$ helyütt érdemes megjegyezni, hogy az a szemlélet, amely a föld és az emberi jogok közötti összefüggést kiemeli, egyre nagyobb elismerést nyer, és egyre gyakrabban megfigyelhető a nemzetközi jogban és a nemzetközi szervek gyakorlatában (ennek kiváló példái a Nemzetközi Büntetőbíróság Főügyészi Hivatalának irányelvei). ${ }^{28}$ Az EJAE 21. cikkéből az EJAB által levezetett kollektív földtulajdon védelmének célja az őslakos népek hagyományos életmódjának, kulturális identitásának, társadalmi struktúrájának, gazdasági viszonyainak, szokásainak, vallásainak és jellegzetes hagyományainak megőrzése és az állam általi tiszteletben tartása. ${ }^{29} \mathrm{Az}$ őslakos népeknek a földjeik és a természetes erőforrások fölötti kollektív tulajdonjoga kizárólag az EJAE-ben és az EJAB joggyakorlatában megfogalmazott garanciális szabályok betartása mellett korlátozható. Egy őslakos közösség tulajdonjoga csak olyan intézkedésekkel korlátozható, amelyek törvényben elöírtak, szükségesek egy demokratikus társadalomban, és arányban állnak a törvényes céllal, amelyet követnek, és amelyek nem tagadják meg egy néptől sem a megélhetést. Az őslakos közösség földjein található természetes erőforrásokat érintő korlátozások nem veszélyeztethetik az őslakos nép megmaradását. ${ }^{30}$

Kiemelendő azonban, hogy az EJAE 21. cikke által garantált védelem nem csak a földtulajdont illeti meg, a védelem tárgyköre ennél szélesebb. Az EJAB ugyanis úgy

\footnotetext{
${ }^{25}$ Sarayakui Kichwa őslakos nép kontra Ecuador ügyben hozott ítélet (2012), 159. pont.

${ }^{26}$ Mayagna (Sumo) Awas Tingni kontra Nicaragua ügy, 2001. augusztus 31-i ítélet, 149. pont [Case of the Mayagna (Sumo) Awas Tingni Community v. Nicaragua. Merits, Reparations and Costs. Judgment of August 31, 2001. Series C No. 79]. Lásd bővebben CHARTERS, Claire: Indigenous Peoples' Rights to Lands, Territories and Resources in the UNDRIP. Articles 10, 25, 26 and 27. In: Hohmann, Jessie-Weller, Marc (eds.): The UN Declaration on the Rights of Indigenous Peoples. A Commentary. Oxford University Press, Oxford, 2018, 396-397. (DOI: 10.1093/law/9780199673223.003.0015); RuIz-CHIRIBOGA (2006): i. m., 59.; RAISz (2010b): i. m., 251.

27 Sarayakui Kichwa őslakos nép kontra Ecuador ügyben hozott ítélet (2012), 159. pont.

${ }^{28}$ A Nemzetközi Büntetőbíróság Föügyészi Hivatala (ICC-OTP) a 2016-es Policy paper on case selection and prioritisation szakpolitikai dokumentumban közölte, hogy a nagyarányú földszerzés (land-grabbing) és a környezetkárosítás számos emberi jogi jogsértést idéz elő, amely a nemzetközi jog szerinti súlyos bủncselekmény tényállását valósíthatja meg, ezért az ICC elsőbbségben részesíti az ezzel kapcsolatos incidensek kivizsgálását. Policy paper on case selection and prioritisation, ICC-OTP, 2016. szeptember 15., 7. pont. https://www.icc-cpi.int/itemsDocuments/20160915_OTP-Policy_Case-Selection_Eng.pdf (2020. 10. 30.). Lásd továbbá az ENSZ emberi jogi főbiztosának jelentését a föld és az emberi jogok közötti viszonyáról, 2014. július 11., E/2014/86, 42-46. pont, valamint az Európai Parlament 2018. július 3-i állásfoglalását a világban az őslakos népeket érő jogsértésekről, beleértve a nagyarányú földszerzést; P8_TA(2018)0279 [European Parliament resolution of 3 July 2018 on violation of the rights of indigenous peoples in the world, including land grabbing].

${ }^{29}$ Kaliña és Lokono népek kontra Suriname ügyben hozott ítélet (2015), 164. pont.

30 Sarayakui Kichwa öslakos nép kontra Ecuador ügyben hozott ítélet (2012), 156. pont. Lásd Yakye Axa őslakos közösség kontra Paraguay ügyben hozott ítélet (2006), 144-145. pont, Saramaka nép kontra Suriname ügyben hozott ítélet (2007), 128-129. pont.
} 
értelmezi az EJAE 21. cikkében szereplő tulajdont, hogy az kiterjed azokra a dolgokra, amelyek birtoklás tárgyai lehetnek, ezen túlmenően pedig minden jogra, amely az adott személy örökségének a része lehet. A tulajdon fogalma kiterjed tehát valamennyi ingó és ingatlan dologra, továbbá valamennyi tárgyi és szellemi értékre. ${ }^{31}$

Az őslakos népek kulturális identitásának védelme szempontjából az EJAB joggyakorlatában nagy jelentőséggel bír a diszkrimináció tilalma is. A Bíróság általános megítélése szerint az EJAE 1. cikk (1) bekezdésében rögzített hátrányos megkülönböztetés tilalmából következik az, hogy a kulturális identitáshoz való jog elismerése elengedhetetlen az őslakos népeket megillető, az EJAE és a nemzeti jogrendek által garantált jogok megértéséhez, tiszteletben tartásához és a joggyakorlás biztosításához. ${ }^{32} \mathrm{Az}$ őslakos közösségeket érintő ügyekben az EJAB többször is megállapította, - jellemzően a tulajdonhoz való jog megsértése esetén - hogy az állam megsértette a diszkrimináció tilalmát azzal, hogy az öslakos közösségek (közös) tulajdonhoz való jogát nem részesítette védelemben ugyanolyan mértékben, mint a többi állampolgár tulajdonjogát. ${ }^{33} \mathrm{~A}$ hátrányos megkülönböztetés tilalmának megsértését - az EJAE 21. cikkel kapcsolatosan - az EJAB megalapozottnak találta több olyan ügyben, ahol az állam nem tette lehetővé az őslakos közösségek számára a földjeik vonatkozásában a megfelelő kijelölési („delimitációs és demarkációs”) eljárás lebonyolítását. Ahogy ezt a Bíróság hangsúlyozta, az őslakosokat illető földek vagy természeti erőforrások puszta jogi vagy elvont elismerése nem bír valódi jelentőséggel, ha a föld nincs fizikailag is meghatározva és lehatárolva. ${ }^{34}$

Az őslakos-specifikus nemzetközi dokumentumok előírják továbbá az őslakosok konzultációs jogát, ${ }^{35}$ amely szoros összefüggésben van a földtulajdon védelmével és a közügyekben való részvétel jogával is ${ }^{36} \mathrm{Az} E J A B$ megítélésében az államot terhelö konzultációs kötelezettség, amellett, hogy több nemzetközi dokumentumban is rögzítésre került, a nemzetközi jog egyik alapelvének tekinthetö. ${ }^{37} \mathrm{~A}$ konzultációs jog nemzetközi elismerése egyenesen a kultúrához való jogból és a kulturális identitáshoz való jogból vezethető le. ${ }^{38} \mathrm{Az}$ EJAB szerint ugyanis:

${ }^{31}$ Mayagna (Sumo) Awas Tingni kontra Nicaragua ügyben hozott ítélet (2001), 144. pont; Yakye Axa őslakos közösség kontra Paraguay ügyben hozott ítélet (2006), 137. pont.

32 Sarayakui Kichwa őslakos nép kontra Ecuador ügyben hozott ítélet (2012), 213. pont.

${ }^{33}$ Mayagna (Sumo) Awas Tingni kontra Nicaragua ügy (2001); Yakye Axa öslakos közösség kontra Paraguay ügy (2006); Saramaka nép kontra Suriname ügy (2007); Xákmok Kásek őslakos közösség kontra Paraguay ügy, 2010. augusztus 24-i ítélet [Case of the Xákmok Kásek Indigenous Community v. Paraguay. Merits, Reparations and Costs. Judgment of August 24, 2010. Series C No. 214]; Sarayakui Kichwa őslakos nép kontra Ecuador ügy (2012); Lhaka Honhat kontra Argentína ügy (2020).

${ }^{34}$ Lásd például Yakye Axa őslakos közösség kontra Paraguay ügyben hozott ítélet (2006), 143. pont; Saramaka nép kontra Suriname ügyben hozott ítélet (2007), 115. pont.

${ }^{35}$ Az őslakos népek jogairól szóló ENSZ Deklaráció (UN Declaration on the Rights of Indigenous Peoples). Az ENSZ Közgyülés 2007. szeptember 13-i határozata, A/RES/61/295, 10.,19., 29.(2), 32.(2) cikk; az ILO 169. sz. egyezménye a bennszülött és törzsi népekröl (The Indigenous and Tribal Peoples Convention no. 169), 1989. június 27., 6. cikk.

${ }^{36}$ BARELLI, Mauro: Free, Prior and Informed Consent in the United Nations Declaration on the Rights of Indigenous Peoples. Articles 10, 19, 29(2) and 32(2). In: Hohmann, Jessie-Weller, Marc (eds.): The UN Declaration on the Rights of Indigenous Peoples. A Commentary, Oxford University Press, Oxford, 2018, 247. (DOI: 10.1093/law/9780199673223.003.0010)

37 Sarayakui Kichwa őslakos nép kontra Ecuador ügyben hozott ítélet (2012), 164. pont.

38 Sarayakui Kichwa öslakos nép kontra Ecuador ügyben hozott ítélet (2012), 159. pont. 
„(...) a kulturális identitás az öslakos közösségeket megillető alapvető - kollektív jellegü - emberi jog, amelyet egy demokratikus, multikulturális és pluralista társadalomnak garantálnia kell. Ez azt jelenti, hogy az államnak kötelezettsége az őslakos népek részére megfelelő konzultációs lehetőséget biztosítani olyan ügyekben, amelyek érintik vagy érinthetik a kulturális és társadalmi életüket, az őslakos nép értékrendszerével, hagyományaival, szokásaival és szervezeti formájával összhangban." 39

A konzultációs eljárás lefolytatásával kapcsolatban az EJAB a nemzetközi jogban megfogalmazott követelményeket támasztja az állammal szemben, amelyek értelmében az államnak az előzetes, szabad, tájékoztatáson alapuló konzultációra kell törekednie. A konzultációt jóhiszeműen, kulturálisan megfelelő módon és megegyezésre törekedve kell folytatni. ${ }^{40}$

A Bíróság hangsúlyozta, hogy olyan nagyszabású projektek és beruházások esetén, amelyek jelentős kihatással vannak az őslakosok földjeire, az államot nemcsak a konzultációs kötelezettség terheli, hanem kötelessége az érintett őslakos nép előzetes, önkéntes és tájékoztatáson alapuló beleegyezését is megszerezni. ${ }^{41}$ A konzultációs jog védelme a közügyekben való részvétel joga alapján is érvényesül az EJAB előtt, amelyet az EJAE 23. cikke garantál. A Lhaka Honhat kontra Argentína ügyben (2020) például a Bíróság megállapította, hogy Argentína elmulasztotta a konzultációs kötelezettséget, amivel - a jogok tiszteletben tartásának kötelezettségével történő együttes értelmezésben [EJAE 1. cikk (1)] - megsértette az őslakos nép tulajdonjogát (EJAE 21. cikk) és a közügyekben való részvétel jogát [EJAE 23. cikk (1)]. ${ }^{42}$

Ahogy a fentiekből is megfigyelhető, a Bíróság a joggyakorlatában az őslakos népek kulturális jogait mindezidáig azáltal részesítette védelmében, hogy azokat jellemzően az ún. első generációs emberi jogokból (polgári és politikai jogok) vezette le. Így a Bíróság összekötötte az első és a második generációs emberi jogokat, minek következtében a két generáció közötti határvonal átjárhatóvá vált, ezzel megerősítve azt a nézetet, miszerint az emberi jogok egyetemesek és oszthatatlanok. ${ }^{43}$

$A z$ őslakos népeket érintő legutóbbi ügyben (Lahka Honhat kontra Argentína) az EJAB a kulturális identitáshoz való jogot immár közvetlenül a második generációs jogokból, pontosabban a kulturális életben való részvétel jogából vezeti le, az

39 Sarayakui Kichwa őslakos nép kontra Ecuador ügyben hozott ítélet (2012), 217. pont.

${ }^{40}$ Lásd például Sarayakui Kichwa őslakos nép kontra Ecuador ügyben hozott ítélet (2012), 177. pont; Lhaka Honhat kontra Argentína ügyben hozott ítélet (2020), 174. és 184. pont.

41 Saramaka nép kontra Suriname ügyben hozott ítélet (2007), 134. pont.

42 Lhaka Honhat kontra Argentína ügyben hozott ítélet (2020), 173. és 184. pont.

${ }^{43}$ PAsqualuccl: i. m., 31. Az emberi jogok csoportosításáról lásd RosAs, Allan-ScheInIN, Martin: Categories and beneficiaries of human rights. In: Hanski, Raija-Suksi, Markku (eds.): An Introduction to the International Protection of Human Rights: A Textbook. Institute for Human Rights, Åbo Akademi University, Abo, 1999, 49-63.; SzALAYNÉ SÁNDOR Erzsébet: $A$ kisebbségvédelem nemzetközi jogi intézményrendszere a 20. században. Gondolat-MTA Kisebbségkutató Intézet, Budapest, 2003, 11-12. Az ENSZ nyomatékosan képviseli azt az álláspontot, hogy az emberi jogok egyetemesek, oszthatatlanok, egymástól kölcsönösen függenek és kapcsolódnak egymáshoz, ami többek között az 1993. évi Bécsi Deklarációban és Cselekvési Programban (5. pont) is rögzítésre került. The World Conference on Human Rights, Vienna Declaration and Programme of Action, 12 July 1993, A/CONF.157/23. 
EJAE 26. cikkére alapozva e jog védelmét. Ez utóbbit példátlan módon, bírósági úton érvényesíthetőnek nyilvánította, tudniillik a Lahka Honhat ügyben hozott ítéletet megelőzően a kulturális jogok csak indirekt módon, az első generációs jogok egyikéből eredeztethetően voltak érvényesíthetők az EJAB előtt (a Lahka Honhat ügy és az EJAE 26. cikk érvényesíthetősége a tanulmány későbbi részében kerül bővebben kifejtésre). A Bíróság értelmezésében a kulturális identitáshoz való jog a kulturális életben való részvétel jogának integrális részét képezi, amelyet többek között az Amerikai Nyilatkozat (XIII. cikk) és a San Salvadori Jegyzökönyv [14. cikk (1)], továbbá a Polgári és Politikai Jogok Nemzetközi Egyezségokmánya (27. cikk), valamint a Gazdasági, Szociális és Kulturális Jogok Nemzetközi Egyezségokmánya (15. cikk) is rögzít. ${ }^{44}$

\section{Lhaka Honhat kontra Argentína ügy (2020)}

2020. február 6-án az EJAB fontos ítéletet hozott a Lhaka Honhat Szövetség kontra Argentína ügyben. Noha a jogvita fö tárgya a földtulajdon kérdése és a kijelölés hiánya volt, a az öslakos közösségeket összefogó kérelmezők elsősorban a kulturális identitásuk védelmét keresték, amely veszélybe került az általuk hagyományosan birtokolt területeken a nem őslakosok által folytatott állattenyésztési és fakitermelési tevékenység, illetve az ezzel kapcsolatos környezetkárosítás miatt.

\subsection{A tényállás}

Az 1980-as évektől kezdve több, az argentínai Salta tartományban élő őslakos közösség kérte folyamatosan az államtól az általuk több évszázad óta birtokolt területekre vonatkozóan a kollektív tulajdonjog elismerését. A tulajdonjog elismerése valamint a területkijelölési eljárás lebonyolítása azért is vált szükségessé, mert a 19. század második felétől kezdődően az őslakosok által lakott területeken nem őslakos származású földművesek telepedtek le (utóbbiakra az EJAB döntés kreolokként hivatkozik). Az általuk folytatott állattenyésztési és fakitermelési tevékenység és kerítéseik felállítása negatív hatással volt az erdőkre és más természeti erőforrásokra, a biodiverzitásban bekövetkezett változások pedig súlyosan veszélyeztették az őslakos közösségek hagyományos életmódját, valamint a vízhez és élelemhez való hozzáférésüket is. ${ }^{45} \mathrm{Ez}$ képezte a panasz fö tárgyát. Emellett a panasz magában foglalta azt a sérelmet is, hogy az érintett területen 1995-ben a Misión la Paz nevű nemzetközi híd előzetes környezeti és társadalmi hatástanulmány, illetve az őslakos közösségekkel való előzetes konzultáció nélkül került felépítésre.

1992-ben az érintett őslakos közösségek létrehozták a Lhaka Honhat („a Mi Földünk") Szövetséget érdekeik érvényesítése és kollektív tulajdonjogaik elismertetése céljából (az ítélet hozatalakor a szövetséget alkotó közösségek száma 132 volt).

\footnotetext{
${ }^{44}$ Lhaka Honhat kontra Argentína ügyben hozott ítélet (2020), 231-233. pont.

${ }^{45}$ Lhaka Honhat kontra Argentína ügyben hozott ítélet (2020), 257-266. pont.
} 
A szövetség nyomására az argentin állam elismerte az őslakos közösségek kollektív földtulajdonát. Az évek folyamán ${ }^{46}$ több megállapodás és rendelet is született erre vonatkozóan. A 2012-es és a 2014-es rendelet az érintett terület nagyobb részét (400.000 ha) az öslakosoknak ítélte oda, a terület kisebbik része (243.000 ha) pedig a nem őslakos földművesek tulajdonában maradt. A gyakorlatban azonban nem került sor olyan állami intézkedésekre, amelyek a rendeletek végrehajtását lehetővé tették volna. A megvalósítás előfeltétele ugyanis egyrészröl az őslakosok és a kreolok lakta területek pontos meghatározása (lehatárolása) lett volna, másrészröl pedig a nem őslakos népesség áttelepítése az őslakosokat megillető területekröl.

A Lhaka Honhat Szövetség az argentin állam felelösségének megállapítására irányuló kérelmét először 1998-ban nyújtotta be az EJABiz-hoz egy jogvédő civil szervezet (CELS) segítségével. Az EJABiz 2006-ban befogadhatónak nyilvánította a kérelmet, és 2012-ben érdemi döntést hozott az ügyben. Megállapította a tulajdonhoz (EJAE 21. cikk), a vélemény- és szólásszabadsághoz (EJAE 13. cikk), a közügyekben való részvételhez (EJAE 23. cikk), valamint a tisztességes eljáráshoz (EJAE 8. cikk) és a bírói védelemhez (EJAE 25. cikk) való jog megsértését, az EJAE 1. cikk (1) bekezdésében és az EJAE 2. cikkében rögzített kötelezettségek elmulasztásával együtt. Az EJABiz előirta a jogsértések orvoslásához szükséges intézkedéseket, amelyeket Argentína nem hajtott végre maradéktalanul, annak ellenére, hogy a határidő 22-szer került meghosszabbításra. ${ }^{47}$ Ebböl kiindulva az EJABiz szerint nem volt valós kilátás arra, hogy Argentína észszerü időn belül meg fogja tenni az intézkedéseket, ezért 2018-ban - azaz 20 évvel az eredeti kérelem benyújtása után - a Lhaka Honhat ügy az EJAB elé került. Az EJAB előtt a kérelmezők - az EJABiz által megállapított jogsértéseken túl - arra is hivatkoztak, hogy a jogképességhez (EJAE 3. cikk), az egyesülési szabadsághoz (EJAE 16. cikk), a mozgás és tartózkodás szabadságához (EJAE 22. cikk) való joguk is megsérült; illetve kérték a kulturális identitáshoz, a megfelelő élelemhez és az egészséges környezethez való jog megsértésének a megállapítását is az EJAE 26. cikke alapján. Ilyen előzmények nyomán kerülhetett sor az ügy elbírálására.

\subsection{Az EJAB döntése}

A Bíróság helyszíni szemlét tartott a jogsértések színhelyén, Salta tartományban, és a bírósági delegáció mind az őslakos közösségek gyülésével, mind pedig a kreolok képviselőivel találkozott. ${ }^{48}$ Szemrevételezte a kérelmezők által említett, a nem őslakos telepesek által felállított kerítéseket és az állatállományukat, továbbá megtekintette a nemzetközi híd helyszínét is. A körültekintő eljárás során (amelyben több civil szervezet adott be amicus curiae-t) hozott ítéletében a Bíróság megállapította több, az EJAE-ben garantált jog megsértését, ezáltal széles alapokra helyezve az őslakosok kulturális identitásának védelmét.

\footnotetext{
46 1991-ben, 1999-ben, 2007-ben, 2012-ben és 2014-ben.

47 Lhaka Honhat kontra Argentína ügyben hozott ítélet (2020), 2. pont.

48 Lhaka Honhat kontra Argentína ügyben hozott ítélet (2020), 10. pont. Az EJAB először a Sarayakui Kichwa ügyben (2012) tartott helyszíni látogatást a bizonyítási eljárás során. Lásd MARINKÁs (2018): i. m., 124.
} 
A kérelem elbírálása során a Bíróság először a tulajdonhoz való jog megsértését vonta górcső alá. Arra a következtetésre jutott, hogy Argentína megsértette az őslakos közösségek tulajdonhoz való jogát (EJAE 21. cikke), amelyet a tisztességes eljáráshoz [EJAE 8. cikk (1)] és a bírói védelemhez [EJAE 25. cikk (1)] való joggal, illetve az EJAE 1. cikk (1) bekezdésében és az EJAE 2. cikkében rögzített kötelezettségével együttesen értelmezett. ${ }^{49} \mathrm{~A}$ Bíróság figyelembe vette, hogy a 2007-es és 2014-es rendeletek értelmében Argentína elismerte, hogy az érintett őslakos közösségeket közösségi tulajdonjog illeti meg az általuk hagyományosan birtokolt területek vonatkozásában. A gyakorlatban azonban az állam nem biztosított az őslakosok számára olyan jogcímet, amely megfelelő jogi biztonságot garantált volna nekik, a kijelölés sem valósult meg, és az őslakosokat megillető területeken a nem őslakos lakosság továbbra is jelen volt. ${ }^{50} \mathrm{~A}$ Bíróság hangsúlyozta, hogy a közösségi tulajdon biztosításához nem elég a közösségi tulajdon elismerése, hanem szükség van az őslakos földekre vonatkozó, az őslakos közösségeket megillető autonómiának és önrendelkezésnek a tiszteletben tartására is. ${ }^{51} \mathrm{~A}$ Bíróság hivatkozott korábbi joggyakorlatára; a Mayagna (Sumo) Awas Tingni közösség kontra Nicaragua, a Sarayakui Kichwa öslakos nép kontra Ecuador, a Saramaka nép kontra Suriname valamint a Kaliña és Lokono népek kontra Suriname ügyekben hozott döntésekre, amelyekben az őshonos közösségeket a nemzetközi jog kollektív alanyaiként ismerte el, akik bizonyos emberi jogokat - ideértve a föld tulajdonjogát is - jogosultak kollektíven gyakorolni, és akiket önrendelkezési jog illet meg.

Az EJAB vizsgálta a 1995-1996-os beruházást is, amelynek keretében az Argentínát és Paraguay-t összekötő, Misión la Paz híd - az őslakosokkal való konzultáció nélkül - felépült. A Bíróság a korábbi joggyakorlatára, a nemzetközi jogra és a szakértői véleményekre is hivatkozva megállapította, hogy Argentína megsértette az arra vonatkozó kötelezettségét, hogy az érintett őshonos közösségek részére előzetes, szabad és tájékoztatáson alapuló konzultációs mechanizmust biztosítson. Ennek következtében - a hátrányos megkülönböztetés tilalmát rögzítö EJAE 1. cikk (1) bekezdésével együttes értelmezésben - sérült az őslakosok tulajdonhoz (EJAE 21. cikk) és közügyekben való részvételéhez való joga (EJAE 23. cikk). ${ }^{52}$

A döntés további részeiben az EJAB foglalkozott a nem őslakos földművesek által okozott környezetkárosítással, valamint az állam felelösségével, amiért a környezetet és az őslakosok jogait nem tudta kellő védelemben részesíteni. A fenti kérdéseket a Bíróság az egészséges környezethez, az élelemhez és a vízhez való jog, illetve a kulturális identitáshoz való jog alapján vizsgálta. Megállapította, hogy a kreolok az illegális fakitermeléssel és az őslakosok földjein folytatott egyéb tevékenységeikkel (állattenyésztés, kerítések felállitása) károsították a környezetet, és korlátozták az őslakosok hagyományos és természetes megélhetését (a vízhez és az élelemhez való hozzáférést). ${ }^{53}$ Ennek eredményeképpen az őslakos közösségek hagyományos életmódja megváltozott, ami a kulturális identitásuk elvesztéséhez vezetett.

\footnotetext{
${ }^{49}$ Lhaka Honhat kontra Argentína ügyben hozott ítélet (2020), 167. pont.

50 Lhaka Honhat kontra Argentína ügyben hozott ítélet (2020), 167. pont.

51 Lhaka Honhat kontra Argentína ügyben hozott ítélet (2020), 153. pont.

52 Lhaka Honhat kontra Argentína ügyben hozott ítélet (2020), 184. pont.

${ }^{53}$ Lhaka Honhat kontra Argentína ügyben hozott ítélet (2020), 240. és 289. pont.
} 
A Bíróság döntésében részletesen elemezte a kultúra fogalmát, és kifejtette a kulturális identitáshoz való jog tartalmát és alapját, a nemzetközi szervezetek gyakorlatára is támaszkodva. ${ }^{54} \mathrm{~A}$ védelem tárgykörét a kultúrához, mint sajátos életformához és annak jellegzetes kulturális jellemzőihez kötötte. ${ }^{55} \mathrm{Az}$ EJAB értelmezése szerint a kulturális identitáshoz való jog védi az egyének azon szabadságát, hogy a közösség többi tagjával egyénileg, vagy mint közösség, azonosuljanak egy vagy több közösséggel vagy társadalmi csoporttal, azzal a céllal, hogy a kultúrájukhoz kapcsolódó életmódot kövessék, és hogy részt vegyenek a kultúrájuk fejlesztésében. ${ }^{56} \mathrm{Az}$ EJAB megítélésében a kulturális identitáshoz való jog védelemben részesíti azokat a megkülönböztető jegyeket, amelyek egy adott társadalmi csoportot jellemeznek, anélkül, hogy tagadná a kultúra történelmi, dinamikus és evolutív jellegét. ${ }^{57}$

Az EJAB idézte korábbi joggyakorlatát, amelyben a kulturális identitást az őslakos közösségeket megillető, alapvető, kollektív emberi jogként ismerte el, amelyet egy demokratikus, multikulturális társadalomnak garantálnia kell. ${ }^{58}$ Emlékeztetett, hogy a kulturális életben való részvétel joga tevőleges magatartást követel az államtól, amely a megfelelő törvényi, hatósági, bírósági, pénzügyi és egyéb intézkedések meghozatalát feltételezi a jog teljes megvalósítása érdekében. A kulturális életben való részvétel jogából az államnak az arra vonatkozó jogvédelmi kötelezettsége is levezethető, hogy védje meg az őslakosokat a harmadik személyektől, amennyiben azok korlátozzák a kulturális életben való részvétel jogának a gyakorlását. ${ }^{59}$

A kreol családok jelenléte és az őslakosok földjein az általuk folytatott munkák, amelyek idegenek voltak az őslakos szokás- és hagyományrendszer szempontjából, az őslakosok kulturális mintáinak és hagyományos életformájának megváltozását idézték elő. A változásokat okozó beavatkozás az őslakosok ősi földjeikhez való szabad hozzáférésének korlátozásával valósult meg. A korlátozás a földeken található természetes erőforrásokhoz való hozzáférést is érintette, ami negatív hatással volt az őslakos közösségek hagyományos víz- és élelemszerzési módjára. Az EJAB megítélésében tehát az őslakos közösségek kulturális identitása megsérült. ${ }^{60} \mathrm{~A}$ Bíróság elismerte, hogy az állam több intézkedést is hozott a meglévő helyzet orvoslására, azok azonban nem akadályozták meg a káros tevékenységek folytatását, hiszen 28 évvel az első kérelem benyújtását követően az idegen állatállományok és a kerítések még mindig jelen vannak az őslakosok földjein. ${ }^{61}$ Ezen kívül az állam nem biztosította az őslakosoknak azt a lehetőséget sem, hogy szabadon rendelkezzenek a földjeik felett, és hogy dönthessenek a földjeiken megvalósuló tevékenységek kap-

54 Lhaka Honhat kontra Argentína ügyben hozott ítélet (2020), 231-242. pont. Ezzel kapcsolatban az EJAB a UNESCO és az ENSZ Gazdasági, Szociális és Kulturális Jogok Bizottsága gyakorlatára hivatkozik.

55 Összhangban többek között a kultúra-fogalomnak az ENSZ Emberi Jogi Bizottsága 23. számú, a kisebbségek jogairól szóló általános kommentárjában bemutatott értelmezéssel.

56 Lhaka Honhat kontra Argentína ügyben hozott ítélet (2020), 240. pont.

${ }^{57}$ Lhaka Honhat kontra Argentína ügyben hozott ítélet (2020), 240. és 284. pont.

${ }^{58}$ Lhaka Honhat kontra Argentína ügyben hozott ítélet (2020), 231. pont. Lásd Sarayakui Kichwa őslakos nép kontra Ecuador ügyben hozott ítélet (2012), 217. pont.

59 Lhaka Honhat kontra Argentína ügyben hozott ítélet (2020), 242. pont.

${ }^{60}$ Lhaka Honhat kontra Argentína ügyben hozott ítélet (2020), 284. pont.

${ }^{61}$ Lhaka Honhat kontra Argentína ügyben hozott ítélet (2020), 287. pont. 
csán. ${ }^{62}$ Mindezekre tekintettel az EJAB megállapította, hogy Argentína megsértette az őslakos közösségeket megillető kulturális életben való részvétel jogát abban az aspektusban, amely a kulturális identitáshoz való jogra vonatkozik, továbbá megsértette az őslakosok egészséges környezethez, megfelelö élelemhez és vízhez való jogát is. Valamennyi fentebb említett joggal kapcsolatban kimondta a Bíróság, hogy azok összefüggésben vannak egymással, és védelemben részesülnek az EJAE 26. cikk alapján. ${ }^{63}$

A jóvátétel meghatározásakor az EJAB figyelembe vette az ügy összetettségét és speciális körülményeit, amelyek abban mutatkoznak meg, hogy az ügy számottevő, őslakos és nem öslakos ember helyzetét érinti, akik egy hatalmas területen élnek. ${ }^{64}$ A Lhaka Honhat ügyben az őslakos népek jogainak megsértéséről az EJAB - az őslakosokat érintő korábbi ügyeitől eltérően - nem egy nagyberuházási projekt kapcsán ítélkezett. A panaszos felek ugyanis magánembereket, a helyi betelepülö földmúveseket vádolták környezetkárosítással, akiket tudniillik szintén jogvédelem illet meg a Földmüvesek és a Vidéki Területeken Dolgozó Más Személyek Jogairól szóló ENSZ Deklaráció értelmében. ${ }^{65}$ Minderre tekintettel a tulajdonhoz való jog megsértésével kapcsolatban az EJAB elrendelte az őslakosok földjeinek (400 000 ha) a kijelölését és lehatárolását, valamint a megfelelő kollektív jogcím megállapítását, amely alapján az őslakosokat a földjeik felett megillető tulajdonjog elismerést nyer. ${ }^{66}$ Elrendelte az öslakosoknak kijelölt területröl a kreol lakosság kitelepítését, azzal a feltétellel, hogy az államnak kerülnie kell az erőszakos intézkedéseket, és mindvégig szem előtt kell tartania a kreol lakosság jogait is ${ }^{67} \mathrm{Az}$ EJAB több környezetvédelmi intézkedés foganatosítására is kötelezte az államot, ${ }^{68}$ valamint utasította egy fejlesztési alap létrehozására az őslakosok kulturális identitásának helyreállítása, illetve az általuk szenvedett anyagi és nem vagyoni károk megtérítése érdekében. ${ }^{69}$

\subsection{A kulturális identitáshoz, az egészséges környezethez,} az élelemhez és a vízhez való jog összefüggéseinek értelmezése

Az ügy tényállása kiváló lehetőséget adott az EJAB-nak a kulturális identitáshoz való jog és az egészséges környezethez való jog közötti összefüggés elemzésére. Az elemzés tárgyát képezte továbbá az élelemhez és a vízhez való jognak a kulturális identitásra gyakorolt hatása is. Az ezzel kapcsolatos megállapítások különösen értékesek a kulturális jogok értelmezése szempontjából, emellett pedig a kiemelt

${ }^{62}$ Lhaka Honhat kontra Argentína ügyben hozott ítélet (2020), 288. pont.

${ }^{63}$ Lhaka Honhat kontra Argentína ügyben hozott ítélet (2020), 289. pont.

${ }^{64}$ Lhaka Honhat kontra Argentína ügyben hozott ítélet (2020), 320. pont.

${ }^{65}$ ENSZ Deklarációja a Földművesek és a Vidéki Területeken Dolgozó Más Személyek Jogairól [United Nations Declaration on the Rights of Peasants and Other People Working in Rural Areas], az ENSZ Közgyülésének 2018. december 17-i határozata, A/RES/73/165.

${ }^{66}$ Lhaka Honhat kontra Argentína ügyben hozott ítélet (2020), 327. pont.

${ }^{67}$ Lhaka Honhat kontra Argentína ügyben hozott ítélet (2020), 329. pont.

${ }^{68}$ Lhaka Honhat kontra Argentína ügyben hozott ítélet (2020), 333. pont.

${ }^{69}$ Lhaka Honhat kontra Argentína ügyben hozott ítélet (2020), 338-339. pont. 
aktualitással bíró környezetvédelem témakörébe is beleilleszkednek, és rávilágítanak a környezeti változások társadalmi hatásaira.

Az egészséges környezethez való jogból kiindulva az EJAB elismerte, hogy az egészséges környezethez való jog egyetemes értékü, és alapvető jognak számít az emberiség létezése szempontjából. ${ }^{70}$ Ezt az álláspontját a Bíróság egy korábbi tanácsadói véleményében mutatta be, amelyben részletesen foglalkozott a környezetvédelem és az emberi jogok közötti összefüggéssel. ${ }^{71} \mathrm{~A}$ jelen ügyben az EJAB kiemelte, hogy a környezetkárosítással kapcsolatos problémák negatív hatással lehetnek az emberi jogok gyakorlására, és különösen érinthetik a kiszolgáltatott helyzetben lévő csoportokat. Ezek közé tartoznak az őslakos népek és más olyan közösségek, amelyek megélhetése a természetes erőforrások rendelkezésre állásától függ. Az államot az arra vonatkozó kötelezettség terheli, hogy a kiszolgáltatott helyzetben lévő csoportokkal szemben az egyenlőség elvét, valamint a hátrányos megkülönböztetés tilalmát szem előtt tartva járjon el. ${ }^{72} \mathrm{Az}$ EJAB hangsúlyozta, hogy az őslakos népek esetén az egészséges környezethez való jog szorosan kapcsolódik az élelemhez, a vízhez és a kulturális identitáshoz való joghoz. Az ügy elbírálása során a Bíróság figyelembe vette a fennálló összefüggést, amely abban nyilvánul meg, hogy a természeti környezetbe való beavatkozás káros hatással lehet mind az élelemhez és a vízhez való jognak, mind a kulturális életben való részvétel jogának a gyakorlására. ${ }^{73}$

Az élelemhez való joggal kapcsolatban az EJAB kiemelte, hogy az nem pusztán fizikai megélhetést foglal magában, hanem kulturális dimenzióval is rendelkezik, különösen az őslakos népek esetében. ${ }^{74}$ Ebből adódóan az élelemhez való jogból levezethető védelem nem bármilyen élelemre vonatkozik, hanem olyan élelemre, amely kulturálisan megfelelőnek tekinthető, azaz amelyet az adott kultúra elfogadhatónak talál. ${ }^{75}$ Ez a megközelítés olyan kritériumok figyelembe vételét is feltételezi, amelyek nem állnak közvetlen összefüggésben a táplálkozással. Ezért a Bíróság megítélésében az élelem az adott társadalmi csoport egyik jellegzetes kulturális jellemzőjének tekinthető, és mint ilyen, védelemben részesül a kulturális identitáshoz való jog alapján. ${ }^{76}$

${ }^{70}$ Lhaka Honhat kontra Argentína ügyben hozott ítélet (2020), 202-203. pont. Bővebben a környezetvédelem és az őslakos népek jogai közötti összefüggésröl lásd ERRICO, Stefania: Control over Natural Resources and Protection of the Environment of Indigenous Territories. Articles 29, 30 and 32. In: Hohmann, Jessie-Weller, Marc (szerk.): The UN Declaration on the Rights of Indigenous Peoples. A Commentary, Oxford University Press, Oxford, 2018, 450-454. (DOI: 10.1093/law/9780199673223.003.0016); MARINKÁs (2018): i. m., 259-264.

${ }^{71}$ Az EJAB 2017. november 15-i tanácsadó véleménye az államnak a természeti környezet védelméhez kapcsolódó kötelezettségeiről az élethez való jog és az integritáshoz való jog tükrében [Advisory Opinion OC23/17 of November 15, 2017 requested by the republic of Colombia]; a továbbiakban: OC-23/17 sz. tanácsadó vélemény, 56-68. pont.

72 Lhaka Honhat kontra Argentína ügyben hozott ítélet (2020), 209. pont.

${ }^{73}$ Lhaka Honhat kontra Argentína ügyben hozott ítélet (2020), 274. pont.

${ }^{74}$ Lhaka Honhat kontra Argentína ügyben hozott ítélet (2020), 254. pont.

75 Lhaka Honhat kontra Argentína ügyben hozott ítélet (2020), 274. pont.

${ }^{76}$ Lhaka Honhat kontra Argentína ügyben hozott ítélet (2020), 274. pont. 
Az élelemhez való joghoz hasonlóan, a vízhez való jog is olyan jellemzőkkel rendelkezik, amelyek miatt összefügg más emberi jogok gyakorlásával. Adott esetben - ahogyan ezt a szóban forgó ügy példázza - a vízhez való jog is a kulturális identitáshoz való joggal állhat szoros összefüggésben. ${ }^{77} \mathrm{Az}$ EJAB kiemelte továbbá, hogy a vízhez való jog az élelemhez való joghoz és a kulturális életben való részvétel jogához hasonlóan, különösen sebezhetőnek bizonyul a természeti környezet változásaival szemben. ${ }^{78} \mathrm{Az}$ őslakosok és képviselőik nem kérték a Bíróságtól a vízhez való jog megsértésének megállapítását, azonban az EJAB célszerünek találta az ügy ez irányú vizsgálatát is, saját joghatóságát pedig e jogsértés megvizsgálására a iura novit curia elvére hivatkozva állapította meg. ${ }^{79}$ Kiemelendő, hogy mind a négy egymáshoz kapcsolódó jognak, nevezetesen az egészséges környezethez, a megfelelő élelemhez, a vízhez való jognak és a kulturális életben való részvétel jogának a megsértését az EJAB az EJAE 26. cikke alapján vizsgálta és állapította meg. Ahogy maga a Bíróság is megjegyezte, erre még nem volt példa egyetlen korábbi ügyben sem. ${ }^{80}$

\subsection{Az EJAE 26. cikke evolutív értelmezésének jelentősége a Lhaka Honhat ügyben}

A Lhaka Honhat Szövetség ügyében ismételten megerösítést nyert, hogy az EJAB hajlandó evolutív módon és több dimenzióban értelmezni az anyagi jogi rendelkezéseket annak érdekében, hogy az őslakos népek kulturális jogainak a lehető leghatékonyabb védelmet nyújtsa. A Lhaka Honhat ügy újító jellege abban nyilvánul meg legföképpen, hogy először ismerte el peres ügyben a Bíróság, hogy a kulturális identitáshoz, az egészséges környezethez, az élelemhez és a vízhez való jog egyenesen az EJAE 26. cikkéből eredeztethető, amely önálóan érvényesíthető az EJAB előtt. $A z$ őslakos népek kulturális identitását az EJAB már nem csak a tulajdonhoz való jogra és az eljárási garanciákra alapozva részesítette védelemben, hanem a kulturális életben való részvétel joga alapján is védelem alá helyezte, amelyet forradalmi módon a szociális, kulturális és gazdasági jogok progresszív megvalósítását elöíró, eddig programjellegűnek tekintett EJAE 26. cikkéből vezetett le. A Yakye Axa kontra Paraguay (2005) és a Sarayakui Kichwa kontra Ecuador ügyekben (2012) megjelent már az EJAE 26. cikke megsértésének a kérdése, azonban mindezidáig az EJAB nem élt azzal a lehetőséggel, hogy az öslakos népek kulturális jogainak védelmét az EJAE 26. cikkére (is) alapozza.

A Lhaka Honhat kontra Argentína ügyben a Bíróság egyértelmüen kimondta, hogy az EJAE 26. cikkében garantált jogok megsértésének elbírálására joghatósággal rendelkezik. ${ }^{81} \mathrm{Az}$ EJAB eddigi gyakorlatában és a szakirodalomban egyaránt vitatott

\footnotetext{
77 Lhaka Honhat kontra Argentína ügyben hozott ítélet (2020), 222. pont.

${ }^{78}$ Lhaka Honhat kontra Argentína ügyben hozott ítélet (2020), 228 és 245. pont.

79 Lhaka Honhat kontra Argentína ügyben hozott ítélet (2020), 200. pont.

80 Lhaka Honhat kontra Argentína ügyben hozott ítélet (2020), 201. pont.

81 Lhaka Honhat kontra Argentína ügyben hozott ítélet (2020), 195-199. pont.
} 
volt, hogy az EJAE 26. cikke érvényesíthető-e a Bíróság előtt. Egyes vélemények szerint az Amerika-közi jogvédelmi mechanizmus alapdokumentumai nem biztosítják a gazdasági, szociális és kulturális jogok érvényesíthetőségét (az oktatáshoz való jog és a szakszervezeti jogok kivételével), ezért az ezt támogató megközelítés nem helytálló, és beleütközik az EJAE és a San Salvadori Jegyzőkönyv rendelkezéseibe. ${ }^{82}$ 2017-ben a Lagos del Campo kontra Peru ügyben az EJAB mégis arra az álláspontra helyezkedett, hogy a gazdasági, szociális és kulturális jogok védelmét előíró EJAE 26. cikke autonóm módon érvényesíthető a Bíróság előtt. ${ }^{83}$ Ezt az álláspontot az EJAB a Lhaka Honhat ügyben is képviselte, mindazonáltal az ügy elbírálása során az EJAE 26. cikkének érvényesíthetőségével kapcsolatban alapvető nézeteltérések alakultak ki a bírák között. Az ügyben eljáró hat bíró közül hárman támogatták a kiterjesztő értelmezést, hárman pedig azt az álláspontot képviselték, hogy az EJAB-nak nincs joghatósága az EJAE 26. cikke megsértésének elbírálására. Az elnöklő bíró szavazata így döntőnek bizonyult abban, hogy az EJAB új alapokra tudja helyezni az őslakosok kulturális identitásának védelmét, amely az EJAE 26. cikkében garantált kulturális jogok bírósági érvényesíthetőségét feltételezi. ${ }^{84}$

Eduardo Ferrer Mac-Gregor Poisot bíró, aki egyike volt azoknak a bíráknak, akik az EJAE 26. cikkének evolutív értelmezését határozottan támogatták, a Lhaka Honhat ügyben született ítéletet mérföldkőnek nevezte. ${ }^{85} \mathrm{Az}$ ügy jelentőségét - az EJAE 26. cikk közvetlen érvényesíthetőségén túl - abban is látja, hogy a Bíróság egyértelmúvé tette, hogy az említett norma alapján az AÁSZ Chartából egyszerre több jogi garancia is levezethető, nevezetesen a kulturális identitáshoz, az egészséges környezethez, az élelemhez és a vízhez való jog védelme. Ezzel egyidejüleg az ítélet segít tisztázni a gazdasági, szociális, kulturális és a környezetvédelmi jogok tartalmát, valamint e jogok védelméhez kapcsolódó, az államot terhelő kötelezettségek terjedelmét. Az ítélet megerősíti az EJAB eddigi megközelítését is, miszerint a polgári, politikai, gazdasági, szociális, kulturális és környezetvédelmi jogok oszthatatlanok és egymással összefüggenek, anélkül hogy e jogok között bármilyen hierarchia lenne. Az államnak tehát egyenlő mértékben kell tiszteletben tartania és biztosítania valamennyi emberi jogot. ${ }^{86}$ Ez különösen fontos az őslakos népek esetében, akiknek a túlélése a természeti erőforrásokhoz kötődik, amely erőforrásokkal

82 Lásd például RuIz-CHIRIBOGA (2013): i. m., 159-186.

83 Lagos del Campo kontra Peru ügy, 2017. augusztus 31-i ítélet [Case of Lagos del Campo v. Peru. Preliminary Objections, Merits, Reparations and Costs. Judgment of August 31, 2017. Series C No. 340]. Az ügy nem érintette a kulturális jogok védelmét, a tényállásból adódóan (a tényállás egy szakszervezeti vezető elbocsátására vonatkozott) a szociális jogokra került a hangsúly.

${ }^{84}$ A Lhaka Honhat ügyhöz öt különvélemény füződik, amelyekben a bírák különböző, figyelemre méltó megközelítéssel tárgyalják az EJAE 26. cikkében garantált gazdasági, szociális és kulturális jogok érvényesíthetőségének, és az EJAB joghatóságának kérdését.

${ }^{85}$ Eduardo Ferrer Mac-Gregor Poisot bíró különvéleménye a Lhaka Honhat kontra Argentína ügyben hozott ítélethez, 4. pont.

${ }^{86}$ Eduardo Ferrer Mac-Gregor Poisot bíró különvéleménye, 87. pont. Eduardo Vio Grossi bíró különvéleményében kifogásolta azt az érvélést, amely úgy foglalható össze, hogy az emberi jogok oszthatatlansága, továbbá a polgári és politikai, illetve a gazdasági, szociális és kulturális jogok közötti összefüggés indokolja, illetve lehetővé teszi a második generációs emberi jogok EJAB előtti érvényesítését. Eduardo Vio Grossi bíró különvéleménye, 91-92. pont. 
mind fizikai, mind spirituális szimbiózisban élnek, mindamellett, hogy folyamatosan küzdenek a szegénységgel és a történelmi igazságtalanságokkal.

A Lhaha Honhat ügyben a kulturális identitás védelme került a figyelem középpontjába, amelyet az elrendelt jóvátétel is erőteljesen bizonyít. A jóvátételi kötelezettségek egyike a már korábban említett fejlesztési alap létrehozása volt az őslakos közösségek javára, és az alap megfelelő forrásokkal való ellátása. Az EJAB joggyakorlatában volt már példa ilyen jellegü jóvátétel elrendelésére, ${ }^{87}$ azonban 2020-ben először mondta ki az EJAB, hogy a fejlesztési alap fő célja az őslakosok kulturális identitásának helyreállítása.

Végül, de nem utolsó sorban, érdemes felhívni a figyelmet az egészséges környezethez való jog kérdésére, amely szintén terítékre került a Lhaka Honhat ügyben. A Bíróság korábban is tárgyalta a környezetvédelmi kérdést a kulturális identitás védelme kontextusában (ez az aspektus markánsan jelent meg például a Kaliña és Lokono népek kontra Suriname ügyben). 2020-ban azonban az egészséges környezethez való jogot az EJAB elsősorban az EJAE 26. cikke alapján részesítette védelemben, párhuzamosan a kulturális identitáshoz való joggal (pontosabban a kulturális életben való részvétel jogával). ${ }^{88}$ Ezt megelőzően az egészséges környezethez való jognak az EJAE 26. cikkén alapuló védelme az EJAB OC-23/17 sz. tanácsadó véleményében nyert megállapítást. ${ }^{89} \mathrm{Az}$ emberi jogok elméleti csoportosításából kiindulva elmondhatjuk tehát, hogy az EJAB legutóbbi gyakorlatában a második generációs (kulturális, gazdasági, szociális) jogok és a harmadik generációs jogok (ez esetben a környezetvédelmi jogok) összekapcsolása is megfigyelhető, az eddig is ismert, az első és a második generációs emberi jogok kölcsönhatása mellett.

\section{Következtetések és zárógondolatok}

Az Amerika-közi emberi jogi dokumentumok nem rögzítik a kulturális identitáshoz való jogot, mindazonáltal az EJAB ítélkezési gyakorlatában az őslakos népek kulturális identitásának védelme az EJAE által garantált, „vitathatatlan” jogok alapján valósul meg, és egyre nagyobb teret nyer. A kulturális identitáshoz való jogot az EJAB először a tulajdonhoz és az élethez való jogból, illetve egyéb első generációs emberi jogokból vezette le. A legújabb joggyakorlatban azonban megállapítást nyert, hogy a kulturális identitáshoz való jog autonóm módon is érvényesíthető a Bíróság előtt az EJAE 26. cikke alapján, úgy, mint az egészséges környezethez, a vízhez és a megfelelő élelemhez való jog is. Az EJAE rendelkezéseinek messzemenően evolutív értelmezése egyrészről az „élő jog” koncepcióval, másrészröl pedig a Bíróságnak az emberi jogok oszthatatlansága melletti elköteleződésével magyarázható. Az EJAB 2020 februárjában hozott ítélete új perspektívába helyezi a kulturális jogok védelmét

${ }^{87}$ Például a Yakye Axa kontra Paraguay (2006); Kaliña és Lokono népek kontra Suriname (2015); Xucuru nép kontra Brazília (2017) ügyekben.

${ }^{88}$ Az egyének jogát az egészséges környezethez a San Salvadori Jegyzőkönyv garantálja (11. cikk), anélkül, hogy lehetővé tenné az egészséges környezethez való jog bírósági érvényesítését.

89 OC-23/17 sz. tanácsadó vélemény, 57. pont. 
az Amerika-közi jogvédelmi mechanizmusban, mindemellett pedig új lehetőségeket tár fel a környezetvédelmi jogok védelme körében is.

Elgondolkodtató, hogy az EJAB által a Lhaka Honhat ügyben hozott ítélet tükrében, amely lehetővé tette a kulturális identitáshoz és az egészséges környezethez való jog messzemenő védelmét, milyen elbírálásban részesül majd az Északi-sarkvidéken élő Athabaskai népeknek az EJABiz-hoz 2013-ben benyújtott petíciója. Az őslakos népek Kanada felelősségének megállapítását kérik a kulturális jogaik megsértése miatt, arra hivatkozva, hogy a jogsértéseket az Északi-sarkvidék felmelegedése okozta. A klímaváltozás pedig az őslakosok szerint Kanadának felróható a korom kibocsátásának nem megfelelő szabályozása miatt. Vajon az EJABiz hajlandó lesz-e az EJAB által kijelölt utat követni, és az őslakosok kulturális jogait védelemben részesíteni a környezetváltozás okozta negatív hatások okán, föleg ha szembesülnie kell a globális felmelegedésért való felelősség kérdésével? Ez a kérdés egyelőre nyitva marad, ugyanis az EJABiz még nem döntött a 2013-ban benyújtott petíció befogadhatóságáról. ${ }^{90}$

${ }^{90}$ Az Északi-sarki Athabaskai Bizottság által az EJABiz-hez benyújtott Kanada elleni panasz megtekinthető: https://earthjustice.org/sites/default/files/AAC_PETITION_13-04-23a.pdf (2020. 10. 30.). 